\title{
A Survey from 2015 to 2019 to Investigate the Occurrence of Pesticide Residues in Dead Honeybees and Other Matrices Related to Honeybee Mortality Incidents in Italy
}

\author{
Marianna Martinello@, Chiara Manzinello, Alice Borin, Larisa Elena Avram, Nicoletta Dainese, \\ Ilenia Giuliato, Albino Gallina and Franco Mutinelli *(D) \\ Istituto Zooprofilattico Sperimentale delle Venezie, NRL for honeybee health, 35020 Legnaro (PD), Italy; \\ mmartinello@izsvenezie.it (M.M.); cmanzinello@izsvenezie.it (C.M.); aliceborin@live.it (A.B.); \\ larisaelena.avram@gmail.com (L.E.A.); ndainese@izsvenezie.it (N.D.); igiuliato@izsvenezie.it (I.G.); \\ agallina@izsvenezie.it (A.G.) \\ * Correspondence: fmutinelli@izsvenezie.it; Tel.: +39-049-8084287
}

Received: 21 November 2019; Accepted: 24 December 2019; Published: 27 December 2019

\begin{abstract}
Honeybee health can be compromised not only by infectious and infesting diseases, but also by the acute or chronic action of certain pesticides. In recent years, there have been numerous reports of colony mortality by Italian beekeepers, but the investigations of these losses have been inconsistent, both in relation to the type of personnel involved (beekeepers, official veterinarians, members of the police force, etc.) and the procedures utilized. It was therefore deemed necessary to draw up national guidelines with the aim of standardizing sampling active ties. In this paper, we present the results of a survey carried out in Italy from 2015 to 2019, following these guidelines. Residues of 150 pesticides in 696 samples were analyzed by LC-MS/MS and GC-MS/MS. On average, 50\% of the honeybee samples were positive for one or more pesticides with an average of 2 different pesticides per sample and a maximum of seven active ingredients, some of which had been banned in Europe or were not authorized in Italy. Insecticides were the most frequently detected, mainly belonging to the pyrethroid group ( $49 \%$, above all tau-fluvalinate), followed by organophosphates (chlorpyrifos, $18 \%$ ) and neonicotinoids (imidacloprid, $7 \%$ ). This work provides further evidence of the possible relationship between complex pesticide exposure and honeybee mortality and/or depopulation of hives.
\end{abstract}

Keywords: honeybee mortality incidents; pesticide; survey; LC-MS/MS; GC-MS/MS

\section{Introduction}

In recent decades, many beekeepers from all over the world have seen a large number of their honeybee colonies dying every year [1,2]. These deaths pose a threat to global food security because honeybees, along with numerous other insect species, provide a fundamental agricultural pollination service $[3,4]$.

Honeybees can be considered a living monitoring system of various aspects of the ecosystem. Their state of health is in fact influenced by different environmental factors, both natural and induced by human activity, such as climate trends, bee diseases, phytosanitary treatments, and beekeeping practices [5]. Honeybees commonly forage within $1.5 \mathrm{~km}$ of their hive (equal to an area of about $7 \mathrm{~km}^{2}$ around the hive) and exceptionally as far as 10 or $12 \mathrm{~km}$, depending on their need for food and its availability [6]. Their body is covered with hairs that can capture atmospheric residues, and they can be contaminated via food resources when gathering pollen and nectar from flowers or through 
water $[7,8]$. Consequently, during foraging flights, bees collect pollen, nectar, plant resins and water, and thus are also valid "samplers" of organic and inorganic chemicals in the environment, which are often taken back to the colony.

In Italy, since 2003, significant honeybee mortality has been recorded in springtime, mainly related to the side-effects of maize seed dressed with neonicotinoid insecticides [9]. These events increased significantly in 2008 leading to the creation, in 2009, of a nationwide surveillance network to monitor the health status of beehives and to properly report bee death incidents and their possible causes. The monitoring network, named ApeNet (2009-2010), initially included about 100 apiaries distributed throughout most of Italy, increasing to 300 and a total of approximately 3000 beehives in 2011 with the BeeNet project (2011-2014), both funded by the Italian ministry of Agriculture, Food and Forestry Policies [10]. These projects have made it possible to assess the health status of hives in Italy, through field observations, surveys, and laboratory analyses aimed at identifying specific pathogens and chemicals, and to study episodes of honeybee colony mortality. A bee emergency service team (BEST) has been created, in charge of receiving beekeepers' reports, assessing severity, organizing and participating in investigations, or coordinating the technicians recruited to deploy them in agreement with the competent authorities [11]. During the five-year monitoring studies, annual and regional variations were observed in pathogens responsible for infection (Deformed Wing Virus, Acute Bee Paralysis Virus, Chronic Bee Paralysis Virus, Nosema ceranae), and in Varroa mite prevalence [2]. Bee bread was often contaminated with at least one pesticide and the number of detected pesticides was positively related to the size of the agricultural area surrounding the apiaries [12]. Of the honeybee samples received following the application of the BEST protocols, 126 were analyzed, of which approximately $50 \%$ were positive for at least one active ingredient. The most frequently detected pesticides were imidacloprid, chlorpyrifos, thiachloprid, chlothianidin, and thiametoxam.

In 2014, the Italian ministry of Health implemented the following regulations: (1) Regulation (EC) No. 1107/2009 [13] concerning the placing of plant protection products (PPPs) on the market (repealing Council Directives 79/117/EEC and 91/414/EEC); (2) Directive 2009/128/EC [14] establishing a framework for Community action to achieve the sustainable use of pesticides; (3) Commission Directive 2010/21/EU amending Annex I to Council Directive 91/414/EEC regarding specific provisions relating to clothianidin, thiamethoxam, fipronil and imidacloprid [15]. Commission Directive 2010/21/EU indicates that member states shall ensure monitoring programs are initiated where and as appropriate to verify the real exposure of honeybees to the aforementioned neonicotinoids in areas extensively used by bees for foraging or by beekeepers. Furthermore, in view of the still frequent beekeeper reports of honeybee death at certain times of the year, and the high degree of public attention paid to this problem, it was considered appropriate for the various Italian regions to adopt a more systematic approach to the management (notification to the competent authority, epidemiological and clinical investigation in the apiary, sampling, laboratory investigation) of bee mortality incidents where pesticide poisoning was suspected. In fact, the application of heterogeneous procedures in the management of bee killing incidents could result in data that may not be representative or exhaustive. Consequently, the General Directorate of Animal Health and Veterinary Medicinal Products of the Italian ministry of Health, with note number 0016168 dated 31 July 2014 [16] issued the "Linee guida per la gestione delle segnalazioni di moria o spopolamento degli alveari connesse all'utilizzo di agrofarmaci" (Guidelines for the management of reports of death or depopulation of bee colonies related to the use of plant protection products). These guidelines provide operational directives for managing these events with the aim of helping to protect beekeeping heritage from poisoning by plant protection products (PPPs), gathering information on the possible causes of death and/or depopulation of beehives, standardizing investigations in terms of the procedures adopted both in the field and at the laboratories responsible for analyzing the sampled dead bees.

The aim of the present study was to investigate the presence of pesticide residues in dead honeybees submitted to our laboratory following the guidelines for managing reports of death or depopulation of bee colonies related to the use of PPPs in Italy, from 2015 to 2019. Sample extraction 
was based on the QuECheRS technique followed by liquid or gas chromatography, both coupled with mass spectrometry (LC-MS/MS and GC-MS/MS), to analyze the selected active substances.

\section{Materials and Methods}

\subsection{Sampling}

Dead honeybee sampling and shipment were carried out by official veterinarians of the Local Health Service specifically trained in beekeeping, in the presence of the beekeeper who issued the notification. The official veterinarians operated in accordance with the abovementioned guidelines, defining the working protocol with all monitoring details, to further standardize the procedure across the different apiaries and beekeepers. Samples consisted of 250-1000 dead honeybees, collected in suitably sealed, properly identified containers. Optionally, samples of comb, bee bread, and vegetable matrices (most frequently leaves, corn seedlings, maize) were also collected. The samples were individually packed in plastic sampling bags to avoid cross contamination, properly identified and the proper storage was guaranteed by immediate freezing after collection. Dead honeybees were collected at the hive entrance or from the ground in front of the hive, bee bread was taken directly from the comb as well as honey. All beehives were opened and clinically inspected in order to evaluate the size of colonies and to estimate the possible impact of the bee killing incidents on the colony itself. Vegetable matrices were collected in the immediate vicinity of the hive or from the near crops treated with pesticides. All samples were stored at $-20{ }^{\circ} \mathrm{C}$ until delivery to the territorially competent Veterinary Institute (IZS) and until toxicological analysis. Samples considered in the present work were delivered to our laboratory between 2015 and 2019. Figure 1 depicts the location of the sampling points in Italy for all matrices and mortality events by year.
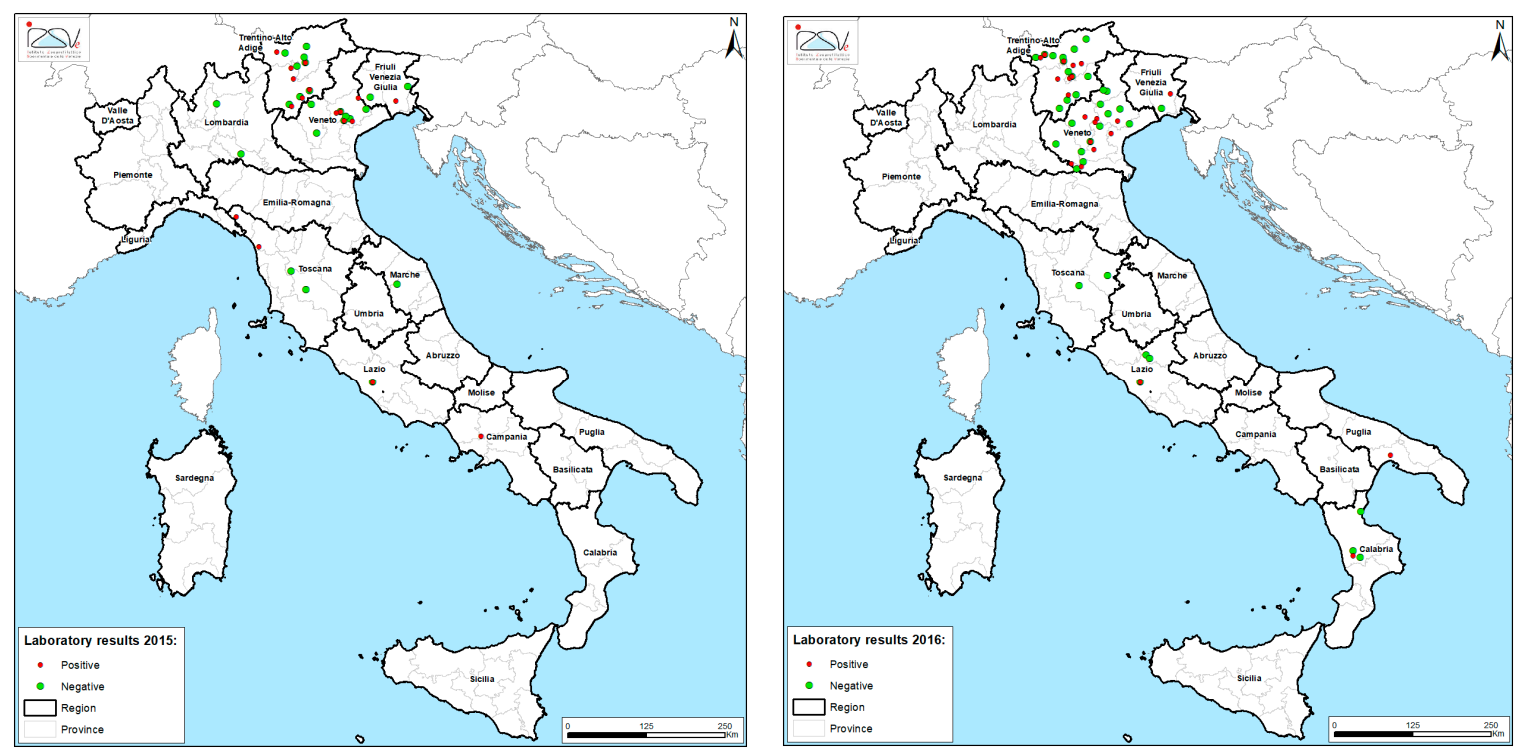

Figure 1. Cont. 


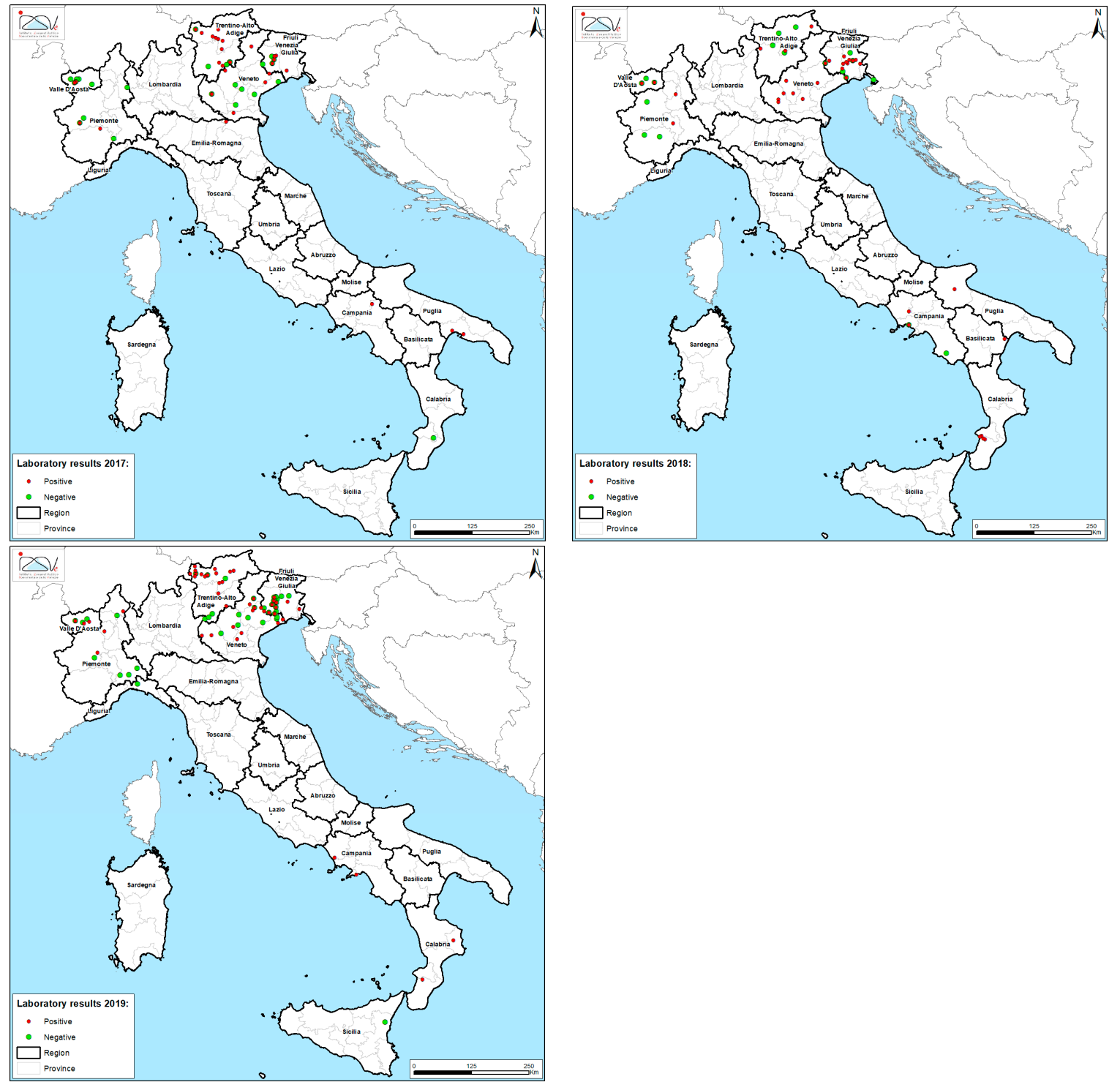

Figure 1. Location of positive and negative samples for each officially reported honeybee mortality event in Italy from 2015 to 2019.

\subsection{Chemicals}

Analytical-grade (98-99.9\% purity) standards of pesticides were supplied by Sigma-Aldrich (Steinheim, Germany) and are listed in Appendix A (Table A1). Pesticide-grade solvents, Supel ${ }^{\mathrm{TM}} \mathrm{QuE}$ Citrate Extraction Tubes and Supel ${ }^{\mathrm{TM}}$ QuE PSA/C18 (EN) Cleanup Tubes were used to extract and purify samples and were purchased from Sigma-Aldrich (Steinheim, Germany). High purity water was prepared using a Milli-Q water purification system (Millipore, Milford, MA, USA). Single standard solutions were prepared in methanol at a concentration of $1000 \mathrm{mg} / \mathrm{L}$. The working standard solutions were prepared by mixing the appropriate amounts of single standard solutions and diluting with methanol to a final concentration of 10 and $1 \mathrm{mg} / \mathrm{L}$. All solutions were stored in the dark in $10 \mathrm{~mL}$ amber bottles at $-20^{\circ} \mathrm{C}$.

\subsection{Sample Preparation}

Samples were prepared following the QuEChERS (Quick Easy Cheap Effective Rugged Safe) approach using the slightly modified method reported by Anastassiades et al. [17]. To obtain proper homogenization and extraction, the samples were previously pulverized with a crushing mill 
(A11 basic IKA-Werke GmbH \& Co. KG, Staufen, Germany) cooled with liquid nitrogen. The samples were processed in duplicate as they were subsequently analyzed with both LC and GC techniques. For extraction, one gram of pollen and vegetable matrices, two grams of bees and wax or $5 \mathrm{~g}$ of honey, were weighed into a centrifuge tube and $10 \mathrm{~mL}$ of water was added. The mixture was vortexed for $5 \mathrm{~min}$, acetonitrile with $0.1 \%$ acetic acid $(10 \mathrm{~mL})$ was added, vortexed for $20 \mathrm{~min}$ and cooled at $-20^{\circ} \mathrm{C}$ for $15 \mathrm{~min}$. To perform the partitioning step, QuEChERS salts EN method (sodium citrate $1 \mathrm{~g}$, sodium hydrogen citrate sesquihydrate $0.5 \mathrm{~g}$, magnesium sulphate $4 \mathrm{~g}$ and sodium chloride $1 \mathrm{~g}$ ) were added and vigorously shaken up and down for $1 \mathrm{~min}$. The mixture was centrifuged and $7 \mathrm{~mL}$ of supernatant was transferred to a tube containing purification dispersive SPE Fatty Samples EN salts (magnesium sulphate $900 \mathrm{mg}$, PSA $150 \mathrm{mg}$ and C18 $150 \mathrm{mg}$ ). The solution was vortexed for $1 \mathrm{~min}$ and centrifuged, and $4 \mathrm{~mL}$ of the supernatant was transferred to a clean tube and evaporated to dryness under vacuum at $45^{\circ} \mathrm{C}$. The residue was dissolved in $0.5 \mathrm{~mL}$ of reconstitution solution, composed of $5 \mathrm{mM}$ ammonium formiate in water with $0.1 \%$ formic acid and $5 \mathrm{mM}$ ammonium formiate in methanol with $0.1 \%$ formic acid (1:1 $v / v)$, and PTFE filtered ( $0.45 \mu \mathrm{m}$ pore size) for analysis by UPLC-MS/MS (Ultra Pressure Liquid Chromatography coupled with tandem mass spectrometry). Samples analyzed using GC-MS/MS were reconstituted with $0.5 \mathrm{~mL}$ of heptane and PTFE filtered $(0.45 \mu \mathrm{m}$ pore size). Both instruments were programmed in MRM (multiple reaction monitor) mode with two selected transitions per molecule.

\subsection{LC-MS/MS Analysis}

The analysis was performed using a Shimadzu LCMS-8040 (Kyoto, Japan), with a tandem quadrupole analyzer, in MRM spectrum mode using an electron spray ionization source in both positive and negative ionization modes. The chromatography was performed on a Raptor (Restek Corporation, Bellefonte, PA, USA) biphenyl column $(10 \mathrm{~cm} \times 2.1 \mathrm{~mm}, 2.7 \mu \mathrm{m}$-particles $)$ with an adequate guard column, thermostated at $35^{\circ} \mathrm{C}$. The mobile phase solvents were $5 \mathrm{mM}$ ammonium formiate in water with $0.1 \%$ formic acid and $5 \mathrm{mM}$ ammonium formiate in methanol with $0.1 \%$ formic acid. The chromatographic eluting conditions were optimized as follows: from $3 \%$ to $10 \% \mathrm{~B}(0-1 \mathrm{~min})$, from $10 \%$ to $55 \%$ B (1-3 min), from $55 \%$ to $100 \%$ B (3-10.5 min), $100 \%$ B maintained for $2.5 \mathrm{~min}$, from $100 \%$ to $3 \% \mathrm{~B}$ in $0.01 \mathrm{~min}$ ), followed by re-equilibration to $3 \% \mathrm{~B}$ for a further $3 \mathrm{~min}$. The total analysis run time was $15 \mathrm{~min}$. The flow rate was $0.4 \mathrm{~mL} / \mathrm{min}$ and the injection volume was $2 \mu \mathrm{L}$. Quantitative and qualitative analyses were performed with LabSolution Insight software based on the two most intensive fragment ion transitions. The matrix matched standards were used for calibration and quantification, prepared by analyzing blank (negative) samples spiked with pesticides after the extraction and purification steps.

\subsection{GC-MS/MS Analysis}

The analysis was performed on a Shimadzu GC-MS TQ8040 equipped with Phenomenex ZB-Semivolatiles columns ( $30 \mathrm{~m}, 0.25 \mathrm{~mm}$ ID, $0.25 \mu \mathrm{m}$ ) and a tandem mass spectrometry detector. A sample volume of $1 \mu \mathrm{l}$ was injected in the splitless mode at an injector temperature of $270{ }^{\circ} \mathrm{C}$. The oven temperature was programmed as follows: initial temperature $60^{\circ} \mathrm{C}$ (held for $2 \mathrm{~min}$ ) increased by $70{ }^{\circ} \mathrm{C} / \mathrm{min}$ to $200{ }^{\circ} \mathrm{C}$; increased by $6{ }^{\circ} \mathrm{C} / \mathrm{min}$ to $300^{\circ} \mathrm{C}$ (held for $2 \mathrm{~min}$ ). The ion source and interface temperature were held at $230{ }^{\circ} \mathrm{C}$ and $280{ }^{\circ} \mathrm{C}$, respectively. The total analysis run time was $23 \mathrm{~min}$. Quantitative and qualitative analyses were performed with LabSolution Insight software based on the two most intensive fragment ion transitions. The matrix matched standards were used for calibration and quantification, prepared by analyzing blank samples spiked with pesticides after the extraction and purification steps.

\section{Results}

Table 1 presents a summary of the pesticides detected in the samples analyzed within 5 years of monitoring. Tables 2 and 3 summarize the main findings by survey year for honeybees and other 
matrices, respectively. Figure 1 shows the location of the positive and negative samples for each officially reported honeybee mortality event.

Table 1. Active ingredients detected in the samples analyzed in the five years of monitoring.

\begin{tabular}{|c|c|c|c|c|c|c|}
\hline \multirow{2}{*}{ Active Ingredient } & \multirow{2}{*}{$\begin{array}{l}\text { Pesticide } \\
\text { Type }^{\mathrm{a}}\end{array}$} & \multirow{2}{*}{ Substance Group } & \multicolumn{2}{|c|}{ Honeybees } & \multicolumn{2}{|c|}{ Other Matrices $^{b}$} \\
\hline & & & $\begin{array}{l}\text { Prevalence } \\
(\%)\end{array}$ & $\begin{array}{c}\text { Range } \\
\text { (ng per Bee) }\end{array}$ & $\begin{array}{l}\text { Prevalence } \\
(\%)\end{array}$ & $\begin{array}{c}\text { Range } \\
\left(\mathrm{mg} \mathrm{kg}^{-1}\right)\end{array}$ \\
\hline 3-ketocarbofuran & metabolite & carbamate & - & - & 0.7 & 0.04 \\
\hline acetamiprid & I & neonicotinoid & 0.8 & $1.9-6.6$ & 1.7 & $0.03-0.06$ \\
\hline acrinathrin & I-A & pyrethroid & 2.0 & $42.7-473$ & 1.7 & $0.2-0.8$ \\
\hline azoxystrobin & $\mathrm{F}$ & strobilurin & 1.2 & $1.0-5.4$ & 2.5 & $0.01-0.02$ \\
\hline boscalid & $\mathrm{F}$ & carboxamide & 1.2 & $<$ LOQ -25.3 & 0.8 & 0.02 \\
\hline bromopropylate & A & benzilate & 1.2 & $5.7-14.5$ & - & - \\
\hline bupirimate & $\mathrm{F}$ & pyrimidinol & 0.8 & $1.6-1.8$ & - & - \\
\hline carbendazim & $\mathrm{F}$ & benzimidazole & 0.4 & 12.9 & 0.8 & 0.04 \\
\hline $\begin{array}{l}\text { chlormequat } \\
\text { chloride }\end{array}$ & PGR & $\begin{array}{l}\text { quarternary } \\
\text { ammonium } \\
\text { compound }\end{array}$ & 0.4 & 1.9 & 0.8 & 0.02 \\
\hline chlorothalonil & $\mathrm{F}$ & chloronitrile & 0.4 & 84.8 & - & - \\
\hline chlorfenvinphos & I-A & organophosphate & 2.8 & $<$ LOQ -162.0 & 7.6 & $0.01-0.4$ \\
\hline chlorpyrifos & I & organophosphate & 12.9 & $1.0-1688.8$ & 8.5 & $0.01-0.5$ \\
\hline chlorpyrifos-mehyl & $\mathrm{I}-\mathrm{A}$ & organophosphate & 6.8 & $1.1-316.0$ & 1.7 & 0.01 \\
\hline chlorpropham & I-PGR & carbamate & 0.8 & 7.2 & - & - \\
\hline clomazone & $\mathrm{H}$ & isoxazolidinone & 0.4 & 1.1 & - & - \\
\hline clothianidin & $\mathrm{I}$ & neonicotinoid & 3.6 & $1.0-17.0$ & - & - \\
\hline coumaphos & I & organothiophosphate & 1.6 & $1.5-50.0$ & 10.2 & $0.01-0.7$ \\
\hline cymoxanil & $\mathrm{F}$ & $\begin{array}{l}\text { cyanoacetamide } \\
\text { oxime }\end{array}$ & - & - & 0.8 & 0.03 \\
\hline cypermethrin & I & pyrethroid & 2.8 & $1.1-7602.0$ & - & - \\
\hline cyprodinil & $\mathrm{F}$ & anilinopyrimidine & 2.8 & $<$ LOQ -484.5 & 0.8 & 1.1 \\
\hline deltamethrin & $\mathrm{I}-\mathrm{M}$ & pyrethroid & - & - & 3.4 & $0.05-0.1$ \\
\hline desmethyl-pirimicarb & I & carbamate & 0.4 & 1.7 & 2.5 & $0.03-0.1$ \\
\hline dimethoate & I-A & organophosphate & 3.2 & $23.3-1647.4$ & 1.7 & \\
\hline dimethomorph & $\mathrm{F}$ & morpholine & 3.2 & $<$ LOQ -4.3 & 9.3 & $0.02-47.0$ \\
\hline dodine & $\mathrm{F}$ & guanidine & - & - & 1.7 & $0.01-0.2$ \\
\hline ethoprophos & $\mathrm{I}-\mathrm{N}$ & organophosphate & 0.4 & 1.7 & 1.7 & 0.2 \\
\hline etofenprox & I & pyrethroid & 6.0 & $<$ LOQ -17.5 & 2.5 & $0.01-0.03$ \\
\hline fipronil & I & phenylpyrazole & 0.4 & 139.6 & 0.8 & 1.8 \\
\hline fludioxonil & $\mathrm{F}$ & phenylpyrrole & 1.2 & $1.0-6.5$ & 0.8 & 0.01 \\
\hline fluopicolide & $\mathrm{F}$ & benzamide & 0.8 & 3.1 & - & - \\
\hline fluopyram & $\mathrm{F}$ & $\begin{array}{l}\text { benzamide, } \\
\text { pyramide }\end{array}$ & 2.0 & $4.0-6.7$ & - & - \\
\hline flutriafol & $\mathrm{F}$ & triazol & 0.4 & 2.0 & - & - \\
\hline folpet & $\mathrm{F}$ & phthalimide & 2.4 & $9.1-46.0$ & 4.2 & $0.3-511.1$ \\
\hline imidacloprid & I & neonicotinoid & 11.6 & $1.2-402.6$ & 3.4 & $0.02-4.1$ \\
\hline indoxacarb & I & oxadiazine & 0.8 & 2 & - & - \\
\hline iprodione & $\mathrm{F}$ & dicarboximide & 1.2 & $3.0-96.3$ & 0.8 & 0.03 \\
\hline kresoxim-methyl & F-B & strobilurin & 0.8 & $2.0-4.2$ & 0.8 & 0.01 \\
\hline metalaxil & $\mathrm{F}$ & phenylamide & 2.0 & $1.0-9.0$ & 5.1 & $0.04-0.4$ \\
\hline metalaxyl-M & $\mathrm{F}$ & phenylamide & - & - & 0.8 & 0.03 \\
\hline methiocarb & I & carbamate & 4.8 & $<$ LOQ -46.5 & 11.0 & $0.01-70.6$ \\
\hline $\begin{array}{l}\text { methiocarb } \\
\text { sulfoxide }\end{array}$ & metabolite & carbamate & 2.4 & $2.5-5.4$ & 2.5 & $0.01-7.6$ \\
\hline methomyl & I-A & carbamate & 3.6 & $1.0-765.0$ & 2.5 & $0.2-0.3$ \\
\hline metrafenone & $\mathrm{F}$ & benzophenone & 0.8 & $1.4-2.8$ & 0.8 & 0.03 \\
\hline metribuzin & $\mathrm{H}$ & triazinone & - & - & 0.8 & 0.08 \\
\hline omethoate & I-A & organophosphate & 3.2 & $4.7-102.2$ & - & - \\
\hline penconazole & $\mathrm{F}$ & triazole & 6.4 & $1.0-90.0$ & 2.5 & $0.01-0.02$ \\
\hline pendimethalin & $\mathrm{H}$ & dinitroaniline & 2.0 & $1.2-4.3$ & 2.5 & $0.01-0.03$ \\
\hline permethrin & I & pyrethroid & 13.3 & $1.6-134,665.0$ & 5.1 & $0.02-2.0$ \\
\hline phosmet & I-A & organophosphate & 3.6 & $1.0-280.8$ & 1.7 & $0.2-0.7$ \\
\hline piperonil butoxide & - & cyclic aromatic & 11.2 & $1.0-66,827.0$ & 11 & $0.01-2.3$ \\
\hline propamocarb & $\mathrm{F}$ & carbamate & 2.8 & $1.1-8.5$ & 2.5 & $0.02-3.6$ \\
\hline
\end{tabular}


Table 1. Cont.

\begin{tabular}{|c|c|c|c|c|c|c|}
\hline Active Ingredient & $\begin{array}{l}\text { Pesticide } \\
\text { Type }^{\text {a }}\end{array}$ & Substance Group & \multicolumn{2}{|c|}{ Honeybees } & \multicolumn{2}{|c|}{ Other Matrices $^{b}$} \\
\hline pyraclostrobin & $\mathrm{F}$ & strobilurin & 0.4 & 6.7 & 1.7 & $0.01-0.3$ \\
\hline pyrimethanil & $\mathrm{F}$ & anilinopyrimidine & 4.4 & $1.0-89.0$ & 6.8 & $0.02-0.8$ \\
\hline rotenone & $\mathrm{I}-\mathrm{A}$ & isoflavone & 0.8 & $1.5-2.4$ & 0.8 & 0.04 \\
\hline s-metolachlor & $\mathrm{H}$ & chloroacetamide & - & - & 0.8 & 0.6 \\
\hline tau-fluvalinate & $\mathrm{I}-\mathrm{A}$ & $\begin{array}{l}\text { synthetic } \\
\text { pyrethroid }\end{array}$ & 38.2 & $1.0-1018.0$ & 53.4 & $0.02-95.9$ \\
\hline tefluthrin & $\mathrm{I}$ & pyrethroid & 3.6 & $1.1-33.1$ & 4.2 & $0.07-1.6$ \\
\hline thiamethoxam & $\mathrm{I}$ & neonicotinoid & 1.6 & $1.8-33.6$ & - & - \\
\hline thifensulfuron-methyl & $\mathrm{H}$ & sulfonylurea & 0.4 & 2.1 & - & - \\
\hline thiodicarb & $\mathrm{I}$ & carbamate & 0.8 & $2.0-5.0$ & - & - \\
\hline thiophanate-methyl & $\mathrm{F}$ & benzimidazole & 0.8 & $5.8-78.6$ & 0.8 & 0.2 \\
\hline tribenuron-methyl & $\mathrm{H}$ & sulfonylurea & 0.4 & 1.0 & - & - \\
\hline trifloxystrobin & $\mathrm{F}$ & strobilurin & 0.8 & $8.1-19.9$ & 0.8 & 1.4 \\
\hline
\end{tabular}

${ }^{a}$ A, acaricide; B, bactericide; $F$, fungicide; $\mathrm{H}$, herbicide; I, insecticide; $\mathrm{N}$, nematicide PGR, plant growth regulator. ${ }^{\mathrm{b}}$ beeswax, beebread, soil, leaves and maize seeds.

Table 2. Pesticides detected in the samples of honeybees analyzed in the five years of monitoring.

\begin{tabular}{|c|c|c|c|c|c|}
\hline Year & n. of Samples & $\begin{array}{c}\text { n. of Positive } \\
\text { Samples (\%) }\end{array}$ & $\begin{array}{l}\text { n. of Pesticides } \\
\text { Detected }\end{array}$ & Most Frequent & Prevalence (\%) \\
\hline \multirow[t]{4}{*}{2015} & 68 & $28(41)$ & 20 & fluvalinate & 50.0 \\
\hline & & & & piperonyl butoxide & 25.0 \\
\hline & & & & cypermethrin & 14.3 \\
\hline & & & & chlorpyrifos & 14.3 \\
\hline \multirow[t]{5}{*}{2016} & 112 & $47(42)$ & 22 & chlorpyrifos & 25.5 \\
\hline & & & & permethrin & 25.5 \\
\hline & & & & tetramethrin & 25.5 \\
\hline & & & & piperonil butoxide & 23.4 \\
\hline & & & & fluvalinate & 21.3 \\
\hline \multirow[t]{3}{*}{2017} & 95 & $48(50)$ & 22 & fluvalinate & 41.7 \\
\hline & & & & chlorpyrifos & 37.5 \\
\hline & & & & methomyl & 16.7 \\
\hline \multirow[t]{4}{*}{2018} & 85 & $63(74)$ & 36 & fluvalinate & 34.9 \\
\hline & & & & imidacloprid & 14.3 \\
\hline & & & & etofenprox & 12.7 \\
\hline & & & & methiocarb & 12.7 \\
\hline \multirow[t]{3}{*}{2019} & 147 & $63(43)$ & 34 & fluvalinate & 46.0 \\
\hline & & & & chlorpyrifos & 15.9 \\
\hline & & & & imidacloprid & 14.3 \\
\hline \multirow[t]{3}{*}{ Sum } & 507 & $249(50)$ & 63 & fluvalinate & 38.2 \\
\hline & & & & permethrin & 13.3 \\
\hline & & & & chlorpyrifos & 12.9 \\
\hline
\end{tabular}


Table 3. Pesticides detected in other matrices analyzed in the five years of monitoring.

\begin{tabular}{|c|c|c|c|c|c|c|}
\hline Year & $\begin{array}{c}\text { n. of } \\
\text { Samples }\end{array}$ & Matrix & $\begin{array}{l}\text { n. of Positive } \\
\text { Samples (\%) }\end{array}$ & $\begin{array}{c}\text { n. of Pesticides } \\
\text { Detected }\end{array}$ & Most Frequent & $\begin{array}{c}\text { Prevalence } \\
(\%)\end{array}$ \\
\hline \multirow[t]{5}{*}{2015} & 18 & & $12(67)$ & 12 & tau-fluvalinate & 83.3 \\
\hline & & & & & tetraconazole & 25.0 \\
\hline & 15 & comb & $10(67)$ & 10 & tau-fluvalinate & 100.0 \\
\hline & 1 & honey & $1(100)$ & 2 & & \\
\hline & 2 & vegetable & $1(50)$ & 3 & & \\
\hline \multirow[t]{7}{*}{2016} & 39 & & $22(56)$ & 15 & tau-fluvalinate & 45.5 \\
\hline & & & & & metalaxyl & 13.6 \\
\hline & & & & & permethrin & 13.6 \\
\hline & 28 & comb & $15(54)$ & 7 & tau-fluvalinate & 67 \\
\hline & 3 & pollen & $2(67)$ & 1 & metalaxyl & 100 \\
\hline & 3 & honey & 0 & & & \\
\hline & 5 & vegetable & $3(60)$ & 6 & & \\
\hline \multirow[t]{6}{*}{2017} & 23 & & $13(57)$ & 10 & tau-fluvalinate & 30.8 \\
\hline & & & & & chlorpyrifos & 23.1 \\
\hline & & & & & desmethyl-pirimicarb & 15.4 \\
\hline & 11 & comb & $10(91)$ & 9 & tau-fluvalinate & 60.0 \\
\hline & 7 & pollen & $3(43)$ & 3 & tau-fluvalinate & 66.7 \\
\hline & 5 & honey & 0 & & & \\
\hline \multirow[t]{7}{*}{2018} & 36 & & $30(83)$ & 26 & tau-fluvalinate & 50 \\
\hline & & & & & methiocarb & 50 \\
\hline & & & & & coumaphos & 26.7 \\
\hline & 11 & comb & $10(91)$ & 10 & tau-fluvalinate & 100.0 \\
\hline & 10 & pollen & $9(90)$ & 14 & tau-fluvalinate & 66.7 \\
\hline & 7 & honey & $5(71)$ & 1 & methiocarb & 100.0 \\
\hline & 8 & vegetable & $6(75)$ & 12 & deltamethrin & 66.7 \\
\hline \multirow[t]{7}{*}{2019} & 73 & & $41(56)$ & 27 & tau-fluvalinate & 58.5 \\
\hline & & & & & pyrimethanil & 19.5 \\
\hline & & & & & dimetomorph & 17.1 \\
\hline & 32 & comb & $25(78)$ & 16 & tau-fluvalinate & 68.0 \\
\hline & 14 & pollen & $11(78)$ & 11 & $\begin{array}{l}\text { tau-fluvalinate- } \\
\text { pyrimethanil }\end{array}$ & 27.3 \\
\hline & 25 & honey & $3(12)$ & 2 & tau-fluvalinate & 66.7 \\
\hline & 2 & vegetable & $2(100)$ & 6 & & \\
\hline \multirow[t]{3}{*}{ Sum } & 189 & & $118(67)$ & 51 & tau-fluvalinate & 53.4 \\
\hline & & & & & methiocarb & 13.6 \\
\hline & & & & & piperonyl butoxide & 11.0 \\
\hline
\end{tabular}

In total, 63 different active ingredients were found in honeybee samples, with concentrations ranging from 0.1 to $134,665 \mathrm{ng} / \mathrm{bee}$, and 51 different active ingredients in the other analyzed matrices (beeswax, bee bread, honey and vegetable matrices), ranging from 0.01 to $359.5 \mathrm{mg} / \mathrm{kg}$. Most investigated samples were positive for at least one active ingredient (53\%) and contaminated by more than one residue: $53 \%$ of the samples were contaminated by at least two different residues, $32 \%$ by at least three, while as many as nine active ingredients were detected in one extreme case, coming from Udine province (North-Eastern Italy).

Insecticides were the most frequently detected active substances (49.2\%) in honeybees (Tables 1 and 2), the most prevalent being the acaricide tau-fluvalinate (38.2\%). Pyrethroid permethrin, the second most frequently found active substance, had a prevalence of $13.3 \%$. Chlorpyrifos was the third most commonly determined pesticide (12.9\%).

Globally, most of the other matrices analyzed (67\%) were positive for at least one active ingredient (Table 3). Again, the acaricide tau-fluvalinate was the most commonly found active ingredient, with a prevalence of $53.4 \%$, followed by the insecticide methiocarb with a prevalence of $13.6 \%$ (also considering the metabolite methiocarb sulfoxide), and the synergist piperonyl butoxide (11.0\%). 


\section{Discussion}

The geographical distribution of the honeybee death events (Figure 1) coincides with the areas in Italy in which intensive agriculture is mainly practiced (such as apple and citrus orchards and vineyards mainly other than maize cultivations).

In honeybees (Tables 1 and 2), the most frequently detected active substances were insecticides with tau-fluvalinate having the highest prevalence. Tau-fluvalinate is a pyrethroid insecticide authorized both as a PPP and for the control of Varroa mite infestation of honeybees in Italy. Miticides have already been found by different studies $[2,18,19]$ to be the most frequent residues in honeybee samples around Europe. The pyrethroid permethrin, the second most frequently identified active ingredient, also has the highest detected concentration. It is a contact insecticide which has not been approved for use in the EU as a PPP, due particularly to its acute toxicity to aquatic organisms. Chlorpyrifos was the third most commonly determined pesticide in honeybees and, being an active ingredient highly toxic to bees, it could represent an important factor affecting colony health. Chlorpyrifos has already been identified as one of the most commonly detected insecticides in bees [20-22]. Neonicotinoids, mainly imidacloprid, were also frequently identified. In Italy, the use of three neonicotinoids, namely imidacloprid, clothianidin, thiamethoxam, and fipronil, was restricted in 2008 due to evidence of their negative effects on honeybee health. In 2013 the EU definitively banned the use of these active ingredients for seed treatment, soil application and foliar treatment of plants and cereals attractive to bees (but use in greenhouses is allowed) $[23,24]$. However, fipronil and all three neonicotinoids (including the restricted ones) screened in our study were detected in our samples. Therefore, despite the current limitations on the use of PPPs containing these active ingredients, according to the present monitoring results, honeybees are still exposed to potentially harmful levels of these pesticides, as already observed in previous studies [25-27]. Fungicides were also often detected (39.3\%) with a wide variety of active ingredients, the most frequently found being penconazole and pyrimethanil. Although there are no restrictions on the use of fungicides on crops during blooming, various studies have shown that the impact of fungicides on honeybee health can be harmful, both due to their direct negative effects on honeybee health [28,29], and through a synergistic action between fungicides and other types of pesticide [30-32]. Our results partially agree with those obtained in a previous study carried out by our laboratory [33], which assessed the presence of pesticides and viruses in dead honeybees following mortality incidents in northeastern Italy in 2014. Compared to this study, in which imidacloprid was the most frequently detected active ingredient, there has now been a reduction in the presence of neonicotinoids, probably due to limitations imposed on their use by the European Commission [23,24]. Tau-fluvalinate and chlorpyrifos were instead confirmed to be among the most frequently identified active ingredients.

With the exception of 2018, the year in which we observed close correspondence between honeybees positive to pesticides and bee kill incident reports, percentage positivity stood at around $44 \%$ in the other monitoring years: a value probably influenced by various factors, as the speed of reporting and the subsequent sampling intervention. The concentration of pesticides in dead honeybees can rapidly decrease within just hours of the poisoning event and, if not properly stored at $-20^{\circ} \mathrm{C}$, samples can reach a level close to environmental residue before being analyzed in the laboratory [20]. The analysis results may be also affected by the severity of the poisoning event (in terms of the active ingredients involved, their concentration, method of administration) and the presence of other bee parasites or stressors (such as viruses and Varroa mite) that can contribute to the weakening of colonies and predisposition to mortality events, even with sublethal concentrations of pesticides $[28,34,35]$.

The honeybee is certainly the most important matrix to be analyzed in case of honeybee mortality incidents, as residues detected in honeybees reflect their exposure both to direct contact with PPPs, biocides, or even veterinary drugs, and to the consumption of contaminated nectar and pollen. However, the analysis of other matrices related to the same incident can help us to better understand the mortality event. For example, bee bread can supply useful data on any PPPs application occurring in the areas surrounding the beehive, while beeswax comb can provide information on exposure over 
a period of time. Unlike other beehive products, beeswax can remain in the hive for many years, thus resulting in an accumulation of various non-polar active ingredients applied in beekeeping and agriculture $[19,35]$. In the present study, most other analyzed matrices $(67 \%)$ were positive for at least one active ingredient (Table 3), and again the acaricide tau-fluvalinate represented the most commonly found active substance, followed by the insecticide methiocarb and the synergist piperonyl butoxide. The most represented matrix was beeswax, with an average of $72 \%$ (70 out of a total of 97 samples) of the samples proving to be contaminated with pesticides, mainly tau-fluvalinate. Bee bread showed $74 \%$ positivity (25/34), and in this case too, the most commonly detected active ingredient was tau-fluvalinate. Being stored inside the beehive, bee bread can be affected by both beekeeper and agricultural activity. For these reasons, however, in the case of a honeybee killing event, we cannot rely on toxicological information provided by beeswax. Vegetable matrices (most frequently leaves, corn seedlings, maize) were contaminated in $70 \%$ of cases (12/17), with the widest variety of active ingredients (27), despite being by far the least numerous matrix received. Honey was also received as a matrix related to honeybee incidents and proved to be contaminated with pesticides in only $20 \%$ of cases; but in three samples the detected pesticide concentration exceeded the limits imposed by the EU (methiocarb 0.05 and $0.7 \mathrm{mg} / \mathrm{kg}$ and tau-fluvalinate $0.05 \mathrm{mg} / \mathrm{kg}$ ) [36]. These results should draw attention to the fact that mortality events are harmful to honeybees, but consumers' health should also be considered. The risk of contamination of edible beehive products, as honey and pollen, but also beeswax, which can then be reused and lead to the transfer of contaminants to honey, cannot be ruled out [37].

It is also worth mentioning the detection of some active ingredients that are no longer authorized but in the past were present in both PPPs and veterinary medicinal products. Authorized active ingredients used against varroosis [38] were among the main sources of honeybee and hive matrices contamination, but so were old apicultural and agricultural acaricides that are now banned, such as bromopropylate (both), chlorfenvinphos, and rotenone (agricultural). The pyrethroid insecticide permethrin, which is highly toxic to honeybees and authorized as a biocide [39], was frequently detected, even in high concentrations, in both honeybees and other matrices. The same applies to the potent multi-purpose pyrethroid insecticide tetramethrin, registered in 1968 and often used to control insects presenting risks to public health, but which is highly toxic for honeybees and has never been authorized for use in crop protection. The insecticide thiodicarb was detected in a few honeybee samples. This insecticide and molluscicide is used to control Lepidoptera, Coleoptera, slugs, other pests of fruit, vegetables, and many other crops, with moderate or high toxicity to honeybees, depending on whether the administration is contact or oral $[36,40]$.

\section{Conclusions}

The data collected following the five-year monitoring survey showed that the application of ministerial guidelines allows the gathering of data on honeybee mortality incidents at national level in a consistent and reliable manner. We have shown that honeybee mortality events are still occurring and widespread, and that honeybees and beehive products are widely exposed to a large number of substances used legally and illegally, in agricultural practices and in beekeeping. In the honeybee matrix, $50 \%$ of the samples were found to be positive, while a greater proportion of the other matrices were contaminated. The honeybee is certainly the most interesting matrix for this study but also the most delicate from an analytical point of view, considering that laboratory results may be affected by various factors, from meteorological aspects to beekeeper reporting times and consequently the intervention of the official veterinarian responsible for sampling. This could potentially result in an underestimation of the problem. As a consequence, beekeepers and official veterinarians need to be highly aware and well informed of this problem to ensure that reporting and samplings are as punctual and prompt as possible. It is also important for the laboratory assigned to sample analysis to be aware of the problems linked to the possibility of pesticide concentration decreasing rapidly in dead bees and therefore of the best ways to conserve the samples before analysis. The pesticide 
panel must also be kept up to date, based on the continuous evolution of the pesticides available on the market. Furthermore, the notification of honeybee killing incidents to the competent national and regional authorities could contribute to increase the awareness of farmers about the possible impact on honeybees of PPPs application. Moreover, this awareness could lead to a more reasonable application of the mitigation measures (established at regional level), such as proper maintenance of PPP application machines together with the use of deflectors to reduce the drifting of active ingredients during treatment, as well as to cut the grass on the orchard or vineyard surface when blossoms are present. The latter measure could strongly reduce the risk of exposure of honeybees to contaminated sources of nectar and pollen, even when the orchard is not blooming.

Our results, based on the appropriate management of bee killing events, as described above, together with laboratory investigations, could contribute to a better understanding of the influence of pesticide mixtures on honeybee health, even at sublethal concentrations. The application, for example, of otherwise sublethal doses of miticides when tau-fluvalinate and coumaphos are simultaneously present in the hive could lead to honeybee mortality [41]. Likewise, great synergy is observed in the laboratory between EBI fungicides at field application rates and pyrethroids used as varroacides [42]. The present type of forensic study cannot demonstrate a direct link between honeybee mortality and pesticide mixtures but does provide us with valid indications of the interactions between active ingredients and therefore the pesticides that warrant further study in the future.

Author Contributions: Conceptualization, F.M., M.M.; Methodology, M.M., A.G.; Validation, M.M. and A.G.; Investigation, M.M., C.M., A.B., L.E.A., N.D., I.G.; Data Curation, C.M.; Writing-Original Draft Preparation, M.M.; Writing-Review \& Editing, F.M., M.M.; Supervision, F.M. All authors have read and agreed to the published version of the manuscript.

Funding: This research received no external funding.

Acknowledgments: The authors wish to thank Claudia Casarotto, GIS Office of Istituto Zooprofilattico Sperimentale delle Venezie, for preparing the maps and Andrea Maroni Ponti, Italian ministry of Health, Directorate General of animal health and veterinary medicines for supporting the program.

Conflicts of Interest: The authors declare no conflict of interest.

\section{Appendix A}

Table A1. Summary of the active substances studied $\left(\mathrm{LOQ}=10 \mu \mathrm{g} \mathrm{kg}^{-1}\right)$.

\begin{tabular}{|c|c|c|c|}
\hline Active Substances & Substance Group & Pesticide Type $^{\text {a }}$ & Detection Method \\
\hline Acetamiprid & neonicotinoid & IN & HPLC-MS \\
\hline Acrinathrin & pyrethroid & IN-AC & GC-ECD \\
\hline Aldicarb * & carbamate & IN-AC-NE & HPLC-MS \\
\hline $\begin{array}{c}\text { Aldicarb-sulfone } \\
\text { (Aldicarb metabolite) * }\end{array}$ & carbamate & IN-AC-NE & HPLC-MS \\
\hline $\begin{array}{c}\text { Aldicarb-sulfoxide } \\
\text { (Aldicarb metabolite) }\end{array}$ & carbamate & IN-AC-NE & HPLC-MS \\
\hline Alpha-Endosulfan * & organochlorine & IN-AC & GC-ECD \\
\hline Azoxystrobin & strobilurin & FU & HPLC-MS \\
\hline Benalaxyl & Acylalanine & FU & HPLC-MS \\
\hline Beta-Endosulfan * & organochlorine & IN-AC & GC-ECD \\
\hline Bifenthrin & pyrethroid & IN-AC & GC-ECD \\
\hline Bitertanol * & triazole & FU & HPLC-MS \\
\hline Boscalid & carboxamide & FU & HPLC-MS \\
\hline Bromopropylate * & benzilate & $\mathrm{AC}$ & HPLC-MS \\
\hline Bupirimate & pyrimidinol & FU & HPLC-MS \\
\hline Captan & phtalimide & FU-BA & GC-ECD \\
\hline Carbaryl * & carbamate & IN-PG & HPLC-MS \\
\hline Carbendazim & benzimidazole & FU & HPLC-MS \\
\hline Carbofuran * & carbamate & IN-AC-NE & HPLC-MS \\
\hline
\end{tabular}


Table A1. Cont.

\begin{tabular}{|c|c|c|c|}
\hline Active Substances & Substance Group & Pesticide Type $^{a}$ & Detection Method \\
\hline $\begin{array}{c}\text { Carbofuran-3-hydroxy } \\
\text { (Carbofuran metabolite) * }\end{array}$ & carbamate & IN-AC-NE & HPLC-MS \\
\hline $\begin{array}{c}\text { Carbofuran-3-keto } \\
\text { (Carbofuran metabolite) * }\end{array}$ & carbamate & IN-AC-NE & HPLC-MS \\
\hline Carboxine & oxathiin & FU & HPLC-MS \\
\hline Chlorfenvinphos * & organophosphate & IN-AC & GC-ECD \\
\hline Chloridazon & pyridazinone & HB & HPLC-MS \\
\hline Chlormequat chloride & quaternary ammonium & PG & HPLC-MS \\
\hline Chlorothalonil & chloronitrile & FU & GC-ECD \\
\hline Chlorpropham & carbamate & HB-PG & GC-ECD \\
\hline Chlorpyrifos & organophosphate & IN & GC-ECD \\
\hline Chlorpyrifos-methyl & organophosphate & IN-AC & HPLC-MS \\
\hline Clomazone & isoxazolidinone & HB & HPLC-MS \\
\hline Clothianidin & neonicotinoid & IN & HPLC-MS \\
\hline Coumaphos* & organophosphate & IN-AC & GC-ECD \\
\hline Cyfluthrin-beta & pyretroid & IN & GC-ECD \\
\hline Cyhalothrin * & pyretroid & IN & GC-ECD \\
\hline Cypermethrin & pyretroid & IN & GC-ECD \\
\hline Cyproconazole & triazole & FU & HPLC-MS \\
\hline Cyprodinil & anilinopyrimidine & FU & HPLC-MS \\
\hline Deltamethrin & pyretroid & IN & GC-ECD \\
\hline Diflubenzuron & benzoylurea & IN & HPLC-MS \\
\hline Dimethoate & organophosphate & IN-AC & HPLC-MS \\
\hline Dimethomorph & morpholine & FU & HPLC-MS \\
\hline Dinotefuran & neonicotinoid & IN & HPLC-MS \\
\hline Dithianon & quinone & FU & HPLC-MS \\
\hline Dodemorph & morpholine (isomer mix) & FU & HPLC-MS \\
\hline Dodine & guanidine & FU & HPLC-MS \\
\hline Endosulfan sulfate & organochlorine & IN-AC & GC-ECD \\
\hline Esfenvalerate & pyretroid & IN & GC-ECD \\
\hline Ethoprophos & organophosphate & IN-NE & GC-ECD \\
\hline Etofenprox & pyretroid & IN & HPLC-MS \\
\hline Etoxazole & diphenyl oxazoline & $\mathrm{AC}$ & HPLC-MS \\
\hline Etridiazole & aromatic hydrocarbon & FU & GC-ECD \\
\hline Fenamidone & imidazole & FU & HPLC-MS \\
\hline Fenamiphos & organophosphate & NE & HPLC-MS \\
\hline $\begin{array}{c}\text { Fenamiphos sulfone } \\
\text { (Fenamiphos metabolite) }\end{array}$ & organophosphate & NE & HPLC-MS \\
\hline $\begin{array}{l}\text { Fenamiphos sulfoxide } \\
\text { (Fenamiphos metabolite) }\end{array}$ & organophosphate & $\mathrm{NE}$ & HPLC-MS \\
\hline Fenarimol * & pyrimidine & FU & HPLC-MS \\
\hline Fenazaquin & quinazoline & IN-AC & HPLC-MS \\
\hline Fenbuconazole & triazole & FU & HPLC-MS \\
\hline Fenothiocarb * & thiocarbamate & $\mathrm{AC}$ & HPLC-MS \\
\hline Fenoxycarb & carbamate & IN & HPLC-MS \\
\hline Fenpropidin & piperidine & FU & HPLC-MS \\
\hline Fenpropimorph & morpholine & FU & HPLC-MS \\
\hline Fenpyroximate & pyrazole & IN-AC & HPLC-MS \\
\hline Fenvalerate * & pyretroid & IN-AC & GC-ECD \\
\hline Fipronil & phenylpyrazole & IN & GC-ECD \\
\hline Flazasulfuron & sulfonylurea & $\mathrm{HB}$ & HPLC-MS \\
\hline Fluazifop-P-butyl & aryloxyphenoxypropionate & $\mathrm{HB}$ & HPLC-MS \\
\hline Flufenacet & oxyacetamide & $\mathrm{HB}$ & HPLC-MS \\
\hline Flufenoxuron * & benzoylurea & IN-AC & HPLC-MS \\
\hline Fludioxonil & phenylpyrrole & FU & HPLC-MS \\
\hline Fluopicolide & benzamide & FU & GC-ECD \\
\hline
\end{tabular}


Table A1. Cont.

\begin{tabular}{|c|c|c|c|}
\hline Active Substances & Substance Group & Pesticide Type $^{\text {a }}$ & Detection Method \\
\hline Fluopyram & benzamide, pyramide & FU-NE & GC-ECD \\
\hline Fluquinconazole & triazole & FU & GC-ECD \\
\hline Flusilazole & triazole & FU & HPLC-MS \\
\hline Flutriafol & triazole & FU & HPLC-MS \\
\hline Folpet & phtalimide & FU & GC-ECD \\
\hline Forchlorfenuron & phenylurea & PG & HPLC-MS \\
\hline Formetanate & formamidine & IN-AC & HPLC-MS \\
\hline Fosthiazate & organophosphate & IN-NE & HPLC-MS \\
\hline Imazalil & imidazole & FU & HPLC-MS \\
\hline Imazosulfuron & sulfonylurea & $\mathrm{HB}$ & HPLC-MS \\
\hline Imidacloprid & neonicotinoid & IN & HPLC-MS \\
\hline Indoxacarb & oxadiazine & IN & GC-ECD \\
\hline Iprodione & dicarboximide & FU & GC-ECD \\
\hline Iprovalicarb & carbamate & FU & HPLC-MS \\
\hline Isopyrazam & pyrazole & FU & GC-ECD \\
\hline Kresoxim-methyl & strobilurin & FU & GC-ECD \\
\hline Lambda-cyhalothrin & pyrethroid & IN & GC-ECD \\
\hline Linuron & urea & $\mathrm{HB}$ & HPLC-MS \\
\hline $\begin{array}{l}\text { Malaoxon (Malathion } \\
\text { metabolite) }\end{array}$ & organophosphate & IN-AC & HPLC-MS \\
\hline Malathion & organophosphate & IN-AC & HPLC-MS \\
\hline Mepanipyrim & anilinopyrimidine & FU & HPLC-MS \\
\hline Metalaxyl & phenylamide & FU & HPLC-MS \\
\hline Metalaxyl-M & phenylamide & FU & HPLC-MS \\
\hline Metamitron & triazinone & $\mathrm{HB}$ & HPLC-MS \\
\hline Metazachlor & chloroacetamide & HB & HPLC-MS \\
\hline Methiocarb & carbamate & IN-MO-RE & HPLC-MS \\
\hline $\begin{array}{l}\text { Methiocarb sulfoxide } \\
\text { (Methiocarb metabolite) }\end{array}$ & carbamate & IN-MO-RE & HPLC-MS \\
\hline Methomyl & carbamate & IN-AC & HPLC-MS \\
\hline Metolachor & chloroacetanilide & $\mathrm{HB}$ & HPLC-MS \\
\hline Metribuzin & triazinone & $\mathrm{HB}$ & HPLC-MS \\
\hline Myclobutanil & triazole & FU & GC-ECD \\
\hline Nytempiram $^{\circ}$ & neonicotinoid & IN & HPLC-MS \\
\hline $\begin{array}{l}\text { Omethoate (Dimethoate } \\
\text { metabolite) * }\end{array}$ & organophosphate & IN-AC & HPLC-MS \\
\hline Oxamyl & carbamate & IN-AC-NE & HPLC-MS \\
\hline Penconazole & triazole & FU & GC-ECD \\
\hline Pencycuron & phenylurea & FU & HPLC-MS \\
\hline Pendomethalin & dinitroaniline & HB & GC-ECD \\
\hline Permethrin * & pyretroid & IN & GC-ECD \\
\hline Phosmet & organophosphate & IN-AC & GC-ECD \\
\hline Piperonyl butoxide $^{\circ}$ & safrole & SY & HPLC-MS \\
\hline Pirimicarb & carbamate & IN & HPLC-MS \\
\hline $\begin{array}{l}\text { Pirimicarb-desmethyl } \\
\text { (Pirimicarb metabolite) }\end{array}$ & carbamate & IN & HPLC-MS \\
\hline Pirimiphos-methyl & organophosphate & IN-AC & HPLC-MS \\
\hline Prochloraz & imidazole & FU & HPLC-MS \\
\hline Procymidone * & dicarboximide & FU & GC-ECD \\
\hline Propamocarb & carbamate & FU & HPLC-MS \\
\hline Propiconazole * & triazole & FU & HPLC-MS \\
\hline Propyzamide & benzamide & $\mathrm{HB}$ & HPLC-MS \\
\hline Pyraclostrobin & strobilurin & FU & HPLC-MS \\
\hline Pyridaben & pyridazinone & IN-AC & HPLC-MS \\
\hline Pyrimethanil & anilinopyrimidine & FU & HPLC-MS \\
\hline Pyriproxyfen & unclassified & IN & HPLC-MS \\
\hline Quinoxyfen * & quinoline & FU & GC-ECD \\
\hline
\end{tabular}


Table A1. Cont.

\begin{tabular}{|c|c|c|c|}
\hline Active Substances & Substance Group & Pesticide Type $^{a}$ & Detection Method \\
\hline Rimsulfuron & sulfonylurea & HB & HPLC-MS \\
\hline Rotenone * & isoflavones & IN & HPLC-MS \\
\hline Spirodiclofen & tetronic acid & IN-AC & HPLC-MS \\
\hline Spirotetramat & tetramic acid & IN & HPLC-MS \\
\hline Tau-Fluvalinate & pyretroid & IN-AC & GC-ECD \\
\hline Tebuconazole & triazole & FU & HPLC-MS \\
\hline Tebufenozide & diacylhydrazine & IN & HPLC-MS \\
\hline Tebufenpyrad & pyrazole & $\mathrm{AC}$ & HPLC-MS \\
\hline Teflubenzuron & benzoylurea & IN & HPLC-MS \\
\hline Tefluthrin & pyrethroid & IN & HPLC-MS \\
\hline Tepraloxydim & cyclohexanedione & HB & HPLC-MS \\
\hline Terbuthylazine & triazine & $\mathrm{HB}$ & HPLC-MS \\
\hline Tetraconazole & triazole & FU & HPLC-MS \\
\hline Tetramethrin * & pyrethroid & IN & GC-ECD \\
\hline Thiabendazole & benzimidazole & FU & HPLC-MS \\
\hline Thiacloprid & neonicotinoid & IN & HPLC-MS \\
\hline Thiamethoxam & neonicotinoid & IN & HPLC-MS \\
\hline Thifensulfuron-methyl & solfonylurea & HB & HPLC-MS \\
\hline Thiobencarb * & thiocarbamate & $\mathrm{HB}$ & HPLC-MS \\
\hline Thiodicarb * & carbamate & IN & HPLC-MS \\
\hline Thiram & dithiocarbamate & FU & HPLC-MS \\
\hline Thiophanate-methyl & benzimidazole & FU & HPLC-MS \\
\hline Tolclofos-methyl & chlorophenyl & FU & GC-ECD \\
\hline Tribenuron-methyl & solfonylurea & HB & HPLC-MS \\
\hline Trifloxystrobin & strobulirin & FU & GC-ECD \\
\hline Triflumuron & benzoylurea & IN & HPLC-MS \\
\hline Triticonazole & triazole & FU & HPLC-MS \\
\hline
\end{tabular}

${ }^{a} \mathrm{AC}$, acaricide; $\mathrm{BA}$, bactericide; FU, fungicide; $\mathrm{HB}$, herbicide; IN, insecticide; $\mathrm{MO}$, molluscicide; NE, nematicide; PG, Plant Growth regulator; RE, repellent; SY, synergist; * substance not approved in Italy; ${ }^{\circ}$ substance not classified in Italy.

\section{References}

1. Goulson, D.; Nicholls, E.; Botías, C.; Rotheray, E.L. Bee declines driven by combined stress from parasites, pesticides, and lack of flowers. Science 2015, 347, 1255957. [CrossRef] [PubMed]

2. Porrini, C.; Mutinelli, F.; Bortolotti, L.; Granato, A.; Laurenson, L.; Roberts, K.; Gallina, A.; Silvester, N.; Medrzycki, P.; Renzi, T.; et al. The status of honey bee health in Italy: Results from the nationwide bee monitoring network. PLoS ONE 2016, 11, e0155411. [CrossRef] [PubMed]

3. Gallai, N.; Salles, J.; Settele, J.; Vaissière, B.E. Economic valuation of the vulnerability of world agriculture confronted with pollinator decline. Ecol. Econ. 2009, 68, 810-821. [CrossRef]

4. Garibaldi, L.A.; Aizen, M.A.; Klein, A.M.; Cunningham, S.A.; Harder, L.D. Global growth and stability of agricultural yield decrease with pollinator dependence. Proc. Natl. Acad. Sci. USA 2011, 108, 5909-5914. [CrossRef]

5. Jacques, A.; Laurent, M.; EPILOBEE Consortium; Ribière-Chabert, M.; Saussac, M.; Bougeard, S.; Budge, G.E.; Hendrikx, P.; Chauzat, M.P. A pan-European epidemiological study reveals honey bee colony survival depends on beekeeper education and disease control. PLoS ONE 2017, 12, e0172591. [CrossRef]

6. Pham-Delègue, M.H. Abeilles; Editions de La Martinière: Paris, France, 1998; p. 47.

7. Lambert, O.; Piroux, M.; Puyo, S.; Thorin, C.; Larhantec, M.; Delbac, F.; Poliquen, H. Bees, honey and pollen as sentinels for lead environmental contamination. Environ. Pollut. 2012, 170, 33-43. [CrossRef]

8. Bonmatin, J.M.; Giorio, C.; Girolami, V.; Goulson, D.; Kreutzweiser, D.P.; Krupke, C.; Liess, M.; Long, E.; Marzaro, M.; Mitchell, E.A.; et al. Environmental fate and exposure; neonicotinoids and fipronil. Environ. Sci. Poll. Res. Int. 2015, 22, 35-67. [CrossRef]

9. Greatti, M.; Barbattini, R.; Stravisi, A.; Sabatini, A.G.; Rossi, S. Presence of the a.i. imidacloprid on vegetation near corn fields sown with Gaucho ${ }^{\circledR}$ dressed seeds. Bull. Insectol. 2006, 59, 99-103. 
10. Rete Rurale. Available online: https:/www.reterurale.it/flex/cm/pages/ServeBLOB.php/L/IT/IDPagina/1369 (accessed on 31 October 2019).

11. Porrini, C.; Sgolastra, F.; Renzi, T. Bee Emergency Service Team (BEST): Bee losses and mortality reports in Italy (2012-2014). Bull. Insectol. 2014, 67, 294.

12. Mutinelli, F.; Sgolastra, F.; Porrini, C.; Medrzycki, P.; Bortolotti, L.; Granato, A.; Gallina, A.; Lodesani, M. The status of honey bee health in Italy: Results from the nationwide monitoring network. In Proceedings of the XI European Congress of Entomology, Naples, Italy, 2-6 July 2018; p. 318.

13. EC. Regulation (EC) No 1107/2009 of the European Parliament and of the Council of 21 October 2009 Concerning the Placing of Plant Protection Products on the Market and Repealing Council Directives 79/117/EEC and 91/414/EEC. OJ EU 2009, L 309; EC: Brussels, Belgium, 2009; pp. 1-50. Available online: https://eur-lex.europa.eu/legalcontent/EN/TXT/?uri=celex\%3A32009R1107 (accessed on 31 October 2019).

14. EC. Directive 2009/128/EC of the European Parliament and of the Council of 21 October 2009 Establishing a Framework for Community Action to Achieve the Sustainable Use of Pesticides. OJ EU 2009, L 309; EC: Brussels, Belgium, 2009; pp. 71-86. Available online: https://eur-lex.europa.eu/legal-content/EN/ALL/?uri=celex\%3A32009L0128 (accessed on 31 October 2019).

15. EC. Commission Directive 2010/21/EU of 12 March 2010 Amending Annex I to Council Directive 91/414/EEC as Regards the Specific Provisions Relating to Clothianidin, Thiamethoxam, Fipronil and Imidacloprid. OJ EU 2010, L 65; EC: Brussels, Belgium, 2010; pp. 27-30. Available online: https:/eur-lex.europa.eu/eli/dir/2010/21/oj (accessed on 31 October 2019).

16. Italian ministry of Health. Linee Guida Per la Gestione Delle Segnalazioni di Moria o Spopolamento Degli Alveari Connesse All'utilizzo di fitoFarmaci [Guideline for the Management of Reporting of Mortality or Dwindling of Beehives Linked to the Use of Pesticides] 0016168-31/07/2014-DGSAF-COD_UO-P; Italian ministry of Health: Rome, Italy, 2014. Available online: http://www.izsvenezie.it/linee-guida-per-la-gestione-delle-segnalazioni-di-moriaospopolamento-degli-alveari-connesse-allutilizzo-di-fitofarmaci (accessed on 31 October 2019).

17. Anastassiades, M.; Lehotay, S.J.; Stajnbaher, D.; Schenck, F.J. Fast and easy multiresidue method employing acetonitrile extraction/partitioning and 'dispersive $\mathrm{SPE}^{\prime}$ for the determination of pesticide residues in produce. JAOAC Int. 2003, 86, 412-431. Available online: http://www.ingentaconnect.com/contentone/aoac/jaoac/2003/ 00000086/00000002/art00023 (accessed on 31 October 2019).

18. Lambert, O.; Piroux, M.; Puyo, S.; Thorin, C.; L'Hostis, M.; Wiest, L.; Bulete, A.; Delbac, F.; Pouliquen, H. Widespread occurrence of chemical residues in beehive matrices from apiaries located in different landscapes of western France. PLoS ONE 2013, 8, e67007. [CrossRef] [PubMed]

19. Calatayud-Vernich, P.; Calatayud, F.; Simò, E.; Picò, Y. Pesticide residues in honey bees, pollen and beeswax: Assessing beehive exposure. Environ. Pollut. 2018, 241, 106-114. [CrossRef] [PubMed]

20. Kiljanek, T.; Niewiadowska, A.; Gaweł, M.; Semeniuk, S.; Borzecka, M.; Posyniak, A.; Pohorecka, K. Multiple pesticide residues in live and poisoned honeybees-Preliminary exposure assessment. Chemosphere 2017, 175, 36-44. [CrossRef] [PubMed]

21. Wiest, L.; Bulete, A.; Giroud, B.; Fratta, C.; Amic, S.; Lambert, O.; Pouliquen, H.; Arnaudguilhem, C. Multi-residue analysis of 80 environmental contaminants in honeys, honeybees and pollens by one extraction procedure followed by liquid and gas chromatography coupled with mass spectrometric detection. J. Chromatogr. A 2011, 1218, 5743-5756. [CrossRef] [PubMed]

22. Mullin, C.A.; Frazier, M.; Frazier, J.L.; Ashcraft, S.; Simonds, R.; van Engelsdorp, D.; Pettis, J.S. High levels of miticides and agrochemicals in North American apiaries: Implications for honey bee health. PLOS ONE 2010, 5, e9754. [CrossRef] [PubMed]

23. EU. Commission Implementing Regulation (EU) No. 485/2013 of 24 May 2013 Amending Implementing Regulation (EU) No 540/2011, as Regards the Conditions of Approval of the Active Substances Clothianidin, Thiamethoxam and Imidacloprid, and Prohibiting the Use and Sale of Seeds Treated with Plant Protection Products Containing Those Active Substances. OJ EU, 2013, L 139; EU: Brussels, Belgium, 2013; pp. 12-26. Available online: http://eur-lex. europa.eu/LexUriServ/LexUriServ.do?uri=OJ:L:2013:139:0012:0026:EN:PDF (accessed on 31 October 2019).

24. EU. Commission Implementing Regulation (EU) No. 781/2013 of 14 August 2013 Amending Implementing Regulation (EU) No 540/2011, as Regards the Conditions of Approval of the Active Substance Fipronil, and Prohibiting the Use and Sale of Seeds Treated with Plant Protection Products Containing this Active Substance. OJ EU 2013, L 219; EU: Brussels, Belgium, 2013; pp. 22-25. Available online: http://eur-lex.europa.eu/LexUriServ/LexUriServ.do?uri=OJ:L: 2013:219:0022:0025:EN:PDF (accessed on 31 October 2019). 
25. Mitchell, E.A.D.; Mulhauser, B.; Mulot, M.; Mutabazi, A.; Glauser, G.; Aebi, A. A worldwide survey of neonicotinoids in honey. Science 2017, 358, 109-111. [CrossRef]

26. Calatayud-Vernich, P.; Calatayud, F.; Simó, E.; Pascual Aguilar, J.A.; Picó, Y. A two-year monitoring of pesticide hazard in-hive: High honey bee mortality rates during insecticide poisoning episodes in apiaries located near agricultural settings. Chemosphere 2019, 232, 471-480. [CrossRef]

27. Gaweł, M.; Kiljanek, T.; Niewiadowska, A.; Semeniuk, S.; Goliszek, M.; Burek, O.; Posyniak, A. Determination of neonicotinoids and 199 other pesticide residues in honey by liquid and gas chromatography coupled with tandem mass spectrometry. Food Chem. 2019, 282, 36-47. [CrossRef]

28. Simon-Delso, N.; Martin, G.S.; Bruneau, E.; minsart, L.-A.; Mouret, C.; Hautier, L. Honeybee colony disorder in crop areas: The role of pesticides and viruses. PLOS ONE 2014, 9, e103073. [CrossRef]

29. Christen, V.; Krebs, J.; Fent, K. Fungicides chlorothanolin, azoxystrobin and folpet induce transcriptional alterations in genes encoding enzymes involved in oxidative phosphorylation and metabolism in honey bees (Apis mellifera) at sublethal concentrations. J. Hazard. Mater. 2019, 377, 215-226. [CrossRef]

30. Johnson, R.M.; Dahlgren, L.; Siegfried, B.D.; Ellis, M.D. Acaricide, fungicide and drug interactions in honey bees (Apis mellifera). PLoS ONE 2013, 8, e54092. [CrossRef] [PubMed]

31. Sánchez-Bayo, F.; Goulson, D.; Pennacchio, F.; Nazzi, F.; Goka, K.; Desneux, N. Are bee diseases linked to pesticides?-A brief review. Environ. Int. 2016, 89, 7-11.

32. Sgolastra, F.; Medrzycki, P.; Bortolotti, L.; Renzi, M.T.; Tosi, S.; Bogo, G.; Teper, D.; Porrini, C.; Molowny-Horas, R.; Bosch, J. Synergistic mortality between a neonicotinoid insecticide and an ergosterol-biosynthesis-inhibiting fungicide in three bee species. Pest Manag. Sci. 2017, 73, 1236-1243. [CrossRef] [PubMed]

33. Martinello, M.; Baratto, C.; Manzinello, C.; Piva, E.; Borin, A.; Toson, M.; Granato, A.; Boniotti, M.B.; Gallina, A.; Mutinelli, F. Spring mortality in honey bees in northeastern Italy: Detection of pesticides and viruses in dead honey bees and other matrices. J. Apic. Res. 2017, 56, 239-254. [CrossRef]

34. Di Prisco, G.; Cavaliere, V.; Annoscia, D.; Varricchio, P.; Caprio, E.; Nazzi, F.; Gargiulo, G.; Pennacchio, F. Neonicotinoid clothianidin adversely affects insect immunity and promotes replication of a viral pathogen in honey bees. Proc. Nat. Acad. Sci. USA 2013, 110, 18466-18471. [CrossRef]

35. Chauzat, M.; Faucon, J. Pesticide residues in beeswax samples collected from honey bee colonies (Apis mellifera L.) in France. Pest Manag. Sci. 2007, 63, 1100-1106. [CrossRef]

36. EU Pesticides Database. Available online: https://ec.europa.eu/food/plant/pesticides/eu-pesticides-database/ public/?event=homepage\&language=EN (accessed on 19 December 2019).

37. Kochansky, J.; Wilzer, K.; Feldlaufer, M. Comparison of the transfer of coumaphos from beeswax into syrup and honey. Apidologie 2001, 32, 119-125. [CrossRef]

38. Mutinelli, F. Veterinary medicinal products to control Varroa destructor in honey bee colonies (Apis mellifera) and related EU legislation-An update. J. Apic. Res. 2016, 55, 78-88. [CrossRef]

39. EU. Regulation (EU) No 528/2012 of the European Parliament and of the Council of 22 May 2012 Concerning the Making Available on the Market and Use of Biocidal Products. OJ EU, 2012, L167; EU: Brussels, Belgium, 2012; pp. 1-123. Available online: https://eur-lex.europa.eu/legal-content/EN/TXT/?uri=CELEX\%3A32012R0528 (accessed on 31 October 2019).

40. PPDB. Pesticide Properties Database. University of Hertfordshire. 2016. Available online: http://sitem.herts. ac.uk/aeru/ppdb/en/index.htm (accessed on 31 October 2019).

41. Johnson, R.M.; Pollock, H.S.; Berenbaum, M.R. Synergistic interactions between in-hive miticides in Apis mellifera. J. Econ. Entomol. 2009, 102, 474-479. [CrossRef]

42. Pilling, E.D.; Jepson, P.C. Synergism between EBI fungicides and a pyrethroid insecticide in the honeybee (Apis mellifera). Pestic. Sci. 1993, 39, 293-297. [CrossRef]

(C) 2019 by the authors. Licensee MDPI, Basel, Switzerland. This article is an open access article distributed under the terms and conditions of the Creative Commons Attribution (CC BY) license (http://creativecommons.org/licenses/by/4.0/). 